\title{
ArcheoSciences
}

Revue d'archéométrie

$36 \mid 2012$

Varia

\section{Palaeovegetational reconstruction of the Krios valley, northern Achaea (Greece): archaeobotanical analysis conducted as part of the Aegialia Survey Project}

La reconstruction de la paléovégétation de la vallée du Krios, nord Achaie (Grèce): les analyses archéobotaniques réalisées dans le cadre de l'Aegialia Survey Projet

Gia Colaianni, Girolamo Fiorentino, Erik Fouache, Angela Pontrandolfo, Alfonso Santoriello and Francesco Scelza

\section{(2) OpenEdition}

Journals

Electronic version

URL: https://journals.openedition.org/archeosciences/3828

DOI: $10.4000 /$ archeosciences.3828

ISBN: 978-2-7535-2243-5

ISSN: $2104-3728$

Publisher

Presses universitaires de Rennes

Printed version

Date of publication: 31 December 2012

ISBN: 978-2-7535-2241-1

ISSN: 1960-1360

Electronic reference

Gia Colaianni, Girolamo Fiorentino, Erik Fouache, Angela Pontrandolfo, Alfonso Santoriello and

Francesco Scelza, "Palaeovegetational reconstruction of the Krios valley, northern Achaea (Greece) archaeobotanical analysis conducted as part of the Aegialia Survey Project", ArcheoSciences [Online], 36 | 2012, Online since 31 December 2014, connection on 28 January 2022. URL: http://

journals.openedition.org/archeosciences/3828 ; DOI: https://doi.org/10.4000/archeosciences.3828 


\title{
Palaeovegetational Reconstruction of the Krios Valley, Northern Achaea (Greece): Archaeobotanical Analysis Conducted as Part of the Aegialia Survey Project
}

\author{
La reconstruction de la paléovégétation de la vallée du Krios, nord Achä̈e (Grèce): \\ les analyses archéobotaniques réalisées dans le cadre de l'Aegialia Survey Projet
}

\author{
G. Colaianni*, G. Fiorentino*, E. Fouache**, A. Pontrandolfo***, \\ A.SA NTORIELLO***a ndF.S CELZA***
}

\begin{abstract}
Since 2001 the Aegialia Survey Project (A.S.P.) has sought to reconstruct the dynamics of human occupation in Aegialia, northern Achaea (Greece). In doing so it has followed a multidisciplinary approach, with the involvement of various skills and institutions. The surveys in the Krios Valley also entailed the recognition and recording of the current flora in the area.

The survey made it possible to identify the site of Kassaneva, characterised by a high concentration of ceramic artefacts near the surface, which were subsequently subjected to chrono-typological analysis and attributed to the Early Helladic II phase ( $3^{\text {rd }}$ millennium B.C.). The archaeological excavation yielded palaeoenvironmental data directly from the ancient context. Specifically, systematic sampling strategies were adopted in order to recover burnt plant remains belonging to arboreal, shrub and herbaceous species.

Together with data from the regional-scale palaeoenvironmental survey, the archaeobotanical analyses enabled us to reconstruct the palaeovegetation in the Bronze Age and the ways in which ancient communities supplied themselves with fuel in numerous ecological areas.

In addition, the recovery of seed and fruit remains provided a rare opportunity to highlight agricultural practices in these marginal and inland areas, raising questions about olive cultivation in Achaea from the Early Helladic period onwards.
\end{abstract}

Résumé : Depuis 2001, l'Aegialia Survey Projet (ASP) a cherché à reconstruire la dynamique de l'occupation humaine dans la région de Aegialia, dans le nord Achaïe (Grèce). Ce faisant, on a suivi une approche multidisciplinaire, avec la participation de diverses compétences et institutions. La recherche dans la vallée de Krios impliquait aussi la reconnaissance et l'enregistrement de la flore actuelle dans la région.

La recherche a permis d'identifier le site de Kassaneva, caractérisée par une forte concentration d'artefacts en céramique sur la surface, qui ont ensuite été attribuée à la phase de l'Helladique Ancien II (3' millénaire avant J.-C.). Les fouilles archéologiques ont fourni des données paléoenvironnementales directement sur ce contexte ancien. Plus précisément, des stratégies d'échantillonnage systématique ont été utilisés afin de récupérer les restes des plantes brûlées appartenant à espèces des arborées, arbustives et herbacées.

Avec les données de la recherche à l'échelle régionale paléoenvironnementale, les analyses archéobotaniques nous ont permis de reconstruire la paléovégétation dans l'Age du Bronze et les façons dont les communautés anciennes se sont approvisionnés en bois dans les différents zones écologiques.

En outre, la récupération des restes des graines et des fruits offert une rare occasion de mettre en évidence les pratiques agricoles dans ces zones marginales et intérieures de la Grèce, ce qui soulève des questions aussi sur la culture des oliviers en Achä̈e a partir de la période Helladique Ancien.

Keywords: Northern Achaia region (Greece), Aegialia Survey Project, Early Helladic II, plant remains, ancient landscape, olive cultivation.

Mots clé : Nord Achaïe (Grèce), Aegialia Survey Projet, Helladique Ancien II, macrorestes végétaux, Ancien paysage, oléiculture.

* Laboratory of Archaeobotany and Palaeoecology, University of the Salento, Lecce-Italy. (colaianni.gia@libero.it) (girolamo.fiorentino@unisalento.it) ** Paris Ouest-Nanterre University (Paris 10), Paris. (eric.g.fouache@wanadoo.fr)

***Laboratory of Archaeology "M. Napoli", Salerno University, Salerno-Italy. (apontrandolfo@unisa.it) (asantori@unisa.it)( frul72@yahoo.com) 
We would like to thank Maria Tsimbidou, Michalis Petropoulos, Zoi Aslamatzidou, Adamantia Vassilogamvrou, Athanassios D. Rizakis, Erofili-Iris Kolia, Gheorghia Z. Alexopoulou and Andreas Vordos for cultural and institutional collaboration. Furthermore, the authors are grateful to Serena De Caro and Maria Luigia Rizzo for the excavation activity and to Fausto Longo, their archaeological coordinator. Particular thanks to M. Ntinou and another anonymous reviewer for comments and suggestions that improve the first version of the text.

\section{INTRODUCTION}

The Landscape Archaeology research conducted by the Aegialia Survey Project (A.S.P.) in the last five years in the Krios valley and the stratigraphic investigations carried out at the Early-Helladic II site of Kassaneva (3000-2500 B.C.) (fig. 1) are the result of cooperation coordinated by the University of Salerno (Italy) with the Laboratory of Archaeobotany and Palaeoecology (University of the Salento, Italy), the Italian Archaeological School in Athens (Italy), the University of Paris Ouest-Nanterre (Paris 10) (France), the $6^{\text {th }}$ Ephorate of Prehistoric and Classical Antiquities in Patras and KERA.

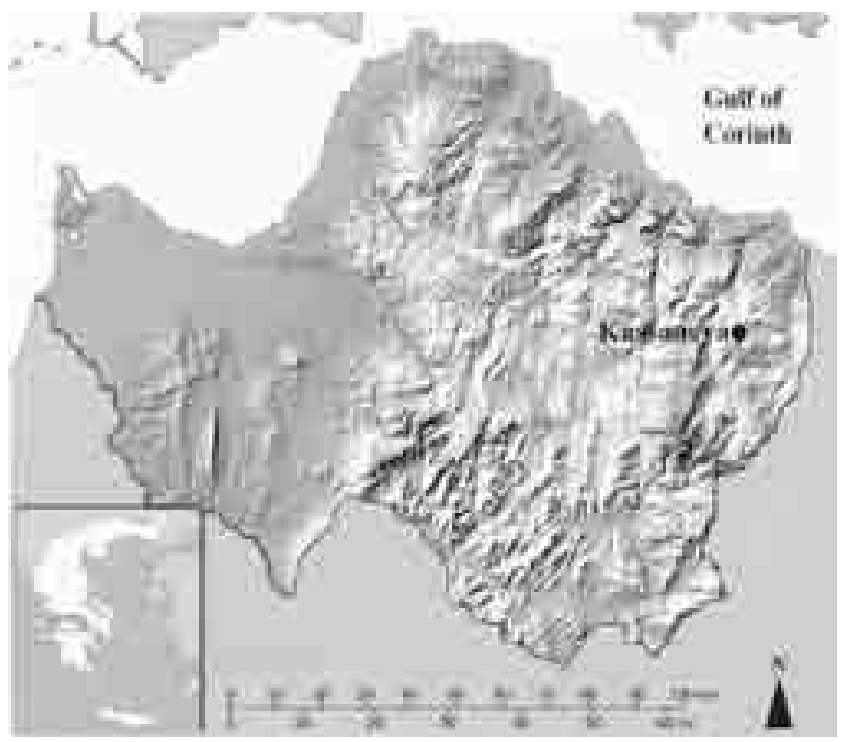

Figure 1: Kassaneva site in the northern Achaia region (Greece). Figure 1 : Site de Kassaneva dans le nord de la région Achaïe (Grèce).

The new research builds on a tradition of archaeological studies that have focused on the various phases of human occupation of Greece, from prehistoric to ancient times (Cavanagh et al., 2005; Cherry et al., 1991; Davis \& Sutton,
1995; Lee, 2001; Lloyd et al., 1985; Simpson, 2007; Sutton, 2000; Wells \& Runnels, 1996).

As part of a long-term project, the specific skills of each research unit were aimed at the reconstruction of the region's ancient landscape and its relationship with the dynamics of human occupation (Bintliff, 2008; Butzer, 1996; Findlow \& Ericson, 1980; Higgs \& Vita Finzi, 1972; Le Roy Ladurie $\&$ Barry, 1962), by means of integrated archaeological and environmental survey methods and a dedicated GIS platform (Santoriello et al., in press).

\section{The geOgraphical SETTING AND HISTORICAL CONTEXT}

The area is characterised by the presence of mountain chains running parallel to the coast, with short, deep valleys such as that of the river Krios below mount Evrostina (about $2000 \mathrm{~m}$ above sea level). The broad river basin, which has an area of about $100 \mathrm{~km}^{2}$, is crossed by tributaries and lesser watercourses that have carved deep valleys of their own, such as the Tholopotamos flowing from the left and the Vathy Lakoma from the right, immediately to the east of the ancient city of Aegira. A ridge joins the area of the city to the mountainous hinterland, which on the right bank of the river Krios is characterised by steep slopes that give way in places to small terraces. On the left bank the landscape is more varied. North of the Goulas and Chalandra, tributaries of the Krios, there are high and broad plateaux that host modern villages. To the south of the Goulas the territory is more mountainous.

The substrate is made up of Plio-Quaternary geological formations. Due to the continuous isostatic lifting of the southern edge of the Gulf of Corinth, these are now found at altitude and are subject to intense erosion. The constant lifting and the distinctive lithology which lends itself to various forms of erosion have generated the steep valleys and the linear regressive erosion of the tributaries of the Krios.

At the foot of the plateau, formed by Plio-calabrian conglomerates, a large fault has been a major factor in the creation of the valley of the Goulas. The fault has also caused the destabilisation of the valley slopes (Fig. 2).

On these slopes are large badlands that formed as a result of both streamcutting erosion and landslides. The underlying marls also favour the creation of badlands and landslides due to their clayey matrix. All the steep valley walls along the river Krios and its tributaries are receding rapidly due to landslides, particularly on the left bank (Petropoulos et al.,2003) . 


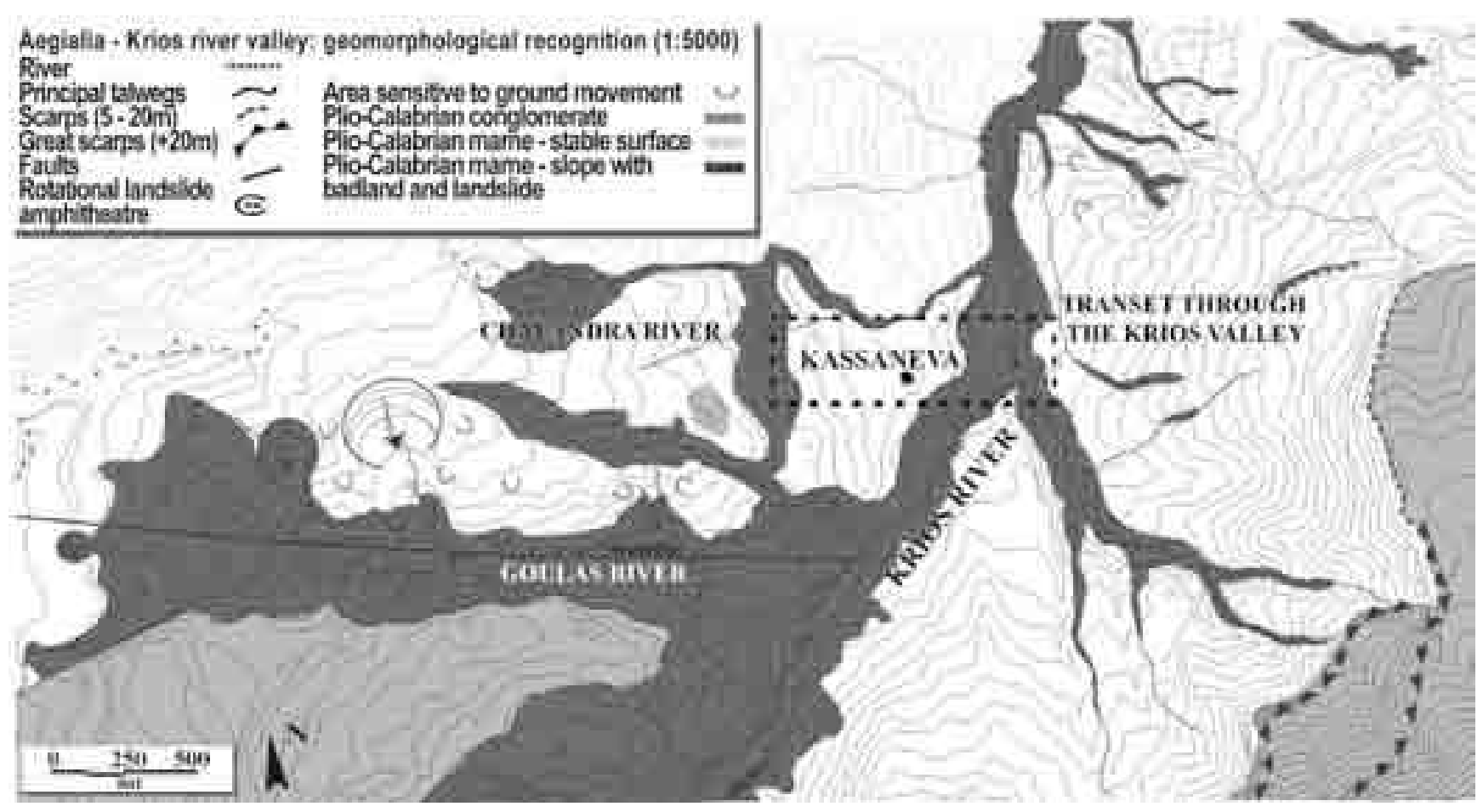

Figure 2: Geomorphological map (Petropoulos et al., 2003, modified). Figure 2 : Carte géomorphologique (Petropoulos et al., 2003, modifiée).

The main archaeological site in the area is that of ancient Aegira. The city was identified on the right bank of the river on a series of terraces rising to a height of $416 \mathrm{~m}$ on the northern side of Mount Evrostina.

On the left bank of the Krios the archaeological literature describes other discoveries of interest, especially in the area lying between the Krios and the Krathis (Petropoulos et al., 2002).

\section{The Aegialia Survey Project and the EXCAVATION OF THE SITE OF KaSSANEVA}

The high concentration of ceramic fragments attributed to the Early Helladic II has made it possible to delimit the area of a settlement on the northern side of the plateau, $250 \mathrm{~m}$ a.s.l., that descends by means of a series of artificial terraces of various dimensions and orientations (Fig. 3). Immediately to the north-east of the upper flat area, two narrow terraces descend in a northerly direction, separating the main plateau from a smaller, lower plateau which, in turn, is part of a system of terraces that descend from east to west.

At the point in which the two different systems of terraces meet, a stretch of wall running along an east-west axis was identified (Fig. 4). Composed of large irregular blocks of conglomerate, it is roughly $25 \mathrm{~m}$ long and $4 \mathrm{~m}$ high. Slightly higher up the slope, another more recent wall was recognised. Built of small stones, the wall marks the limit of the upper terrace. Linked to it is another stretch of wall running along a north-south axis; now obscured by dense vegetation, it acts as a retaining wall for another, larger terrace.

The various systems of terraces are clearly part of a single site, probably a fully fledged settlement from which numerous fragments of protohistoric ceramics have been recovered (Petropoulos et al., 2005).

The archaeological excavation of a roughly $100 \mathrm{~m}^{2}$ portion of the plateau has brought to light numerous remains of walls. These are mainly limestone blocks and stones, bound with clay and containing a central filling of clay and small stones, of which only the bottom row is conserved. These stretches of walls, discovered in association with fragments of pots used for the preparation and storage of food, are believed to have belonged to structures for human habitation (Petropoulos et al., 2006). It is not clear however whether the remains discovered here correspond to continuous or merely seasonal forms of occupation of the plateau. 


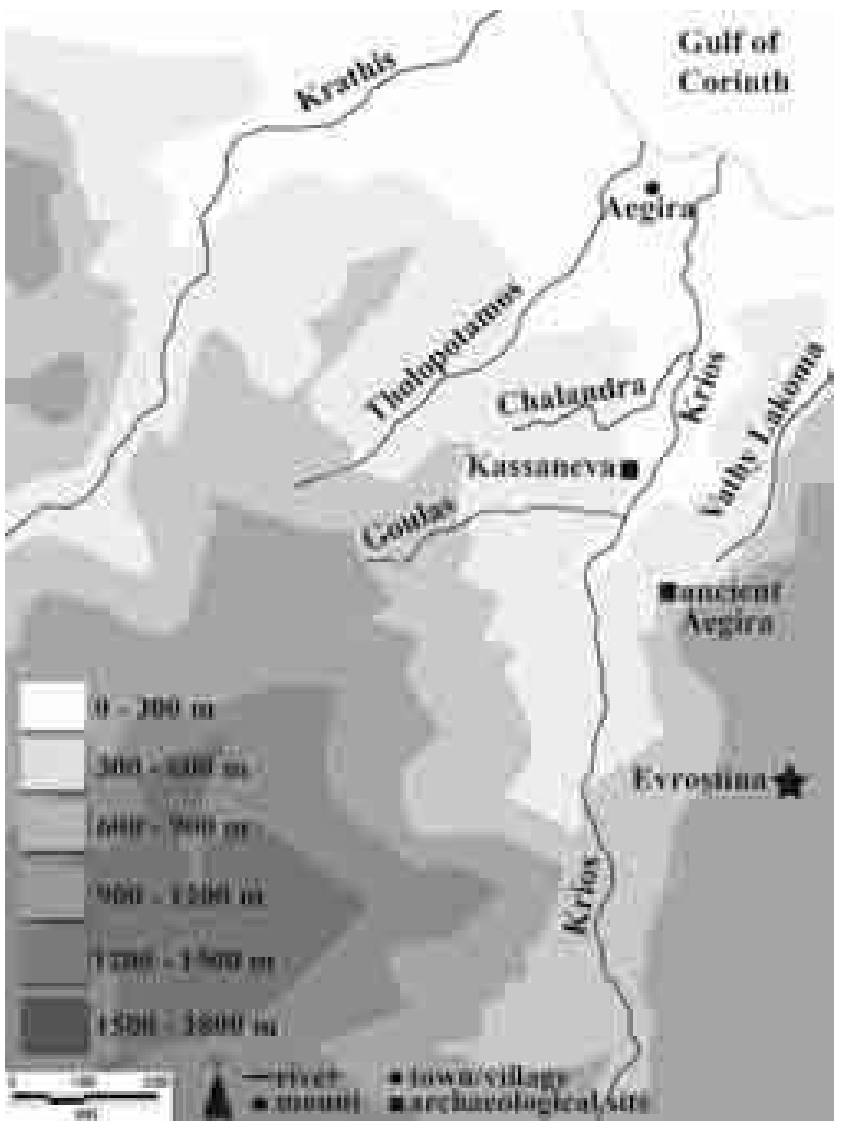

Figure 3: Altimetric map (Petropoulos et al., 2004, modified). Figure 3: Carte altimétrique (Petropoulos et al., 2004, modifiée).

\section{RECONSTRUCTION OF THE PALAEOVEGETATION: INTEGRATED ANALYSES OF MODERN PLANT COVER AND ANCIENT MACROREMAINS}

The modern landscape represents the starting point for the reconstruction - by means of a reverse process - of the variations in regional plant coverage over time.

The analysis began with a survey of the current vegetation, focusing on a $1.7 \mathrm{~km}^{2}$ transect stretching from the plateau to the hilly country further inland, which recorded the geomorphological and ecological characteristics of the individual stations considered (Fig. 2).

The second approach focused on the archaeological deposit and the archaeobotanical analysis at the site of Kassaneva. Standard samples of sediment were taken from the various archaeological contexts being excavated, from hearths and floors in household structures, and were subsequently subjected to flotation in order to recover plant macroremains
(Fig. 5). The selected material was analysed at the Laboratory of Archaeobotany and Palaeoecology of the University of the Salento by stereomicroscope (Nikon SMZ 645) and metallographic microscope (Nikon Eclipse ME600), comparing the recorded characteristics with reference collections of seeds/fruits and charcoals of Mediterranean plants as well as traditional atlases of reference (Abbate Edlmann et al., 1994; Andergerg, 1994; Cambini, 1967; Greguss, 1955; Jacomet, 2006; Jacquiot, 1955; J.M. Renfrew, 1973; Schweingruber, 1990).

\section{Results}

\section{Modern vegetation}

The survey of the vegetation around the site has allowed us to recognize the syntaxonomic order of Quercetalia ilicis, common to the whole of northern Achaea. This is a floristic association found in the thermo-Mediterranean belt and particularly in coastal, hilly and sub-mountainous areas (Verroios \& Georgiadis, 2011). The altitude of the plateau, $250 \mathrm{~m}$ above sea level, in the transitional climate zone between the coast and the inland hills, favours the presence within this order of two vegetational alliances, Olea-Ceratonion and Quercion ilicis. The first characterizes highly xerophilous environments, populated by sclerophyllous Mediterranean maquis (olive, mastic, ceratonia, Aleppo pine etc.), whereas the second characterizes is usually found in thermo-mesophilous environments, with oaks, terebinth, European black pine, etc. (Dafis, 1976; Tan et al., 2001) (Fig. 6).

Another aspect of the plateau is the deep impact of the agricultural practices on the natural environment. The presence of human beings is clear from the intensive agriculture, based on olive and citrus groves. Completing the picture of the rural landscape are the numerous retaining walls of the terraces typical in much of the Peloponnese (Price \& Nixon, 2005), built in our area during the Early Helladic Period, as well as Kassaneva excavation testifies (Petropoulos et al.,2004) .

Traces of natural vegetation are present in those parts of the plateau that are not suitable for agriculture due to outcrops of bedrock or the steepness of the land at its edges. These areas are host to Kermes oak, isolated remnants of the original maquis (Malanson \& Trabaud, 1988; Trabaud, 1991; Tsiouvaras, 1987). The latter is associated with shrubs, such as mastic and tree heath, typical of the secondary maquis, probably of anthropic origin (Gavrielides, 1976; Riba, 1997; Tomaselli, 1977). 
Figure 4: Excavation area and two ancient systems of terraces (Petropoulos et al., 2004, modified).

Figure 4: La zone de fouille archéologique et les deux anciens systèmes de terrasses (Petropoulos et al., 2004, modifié)

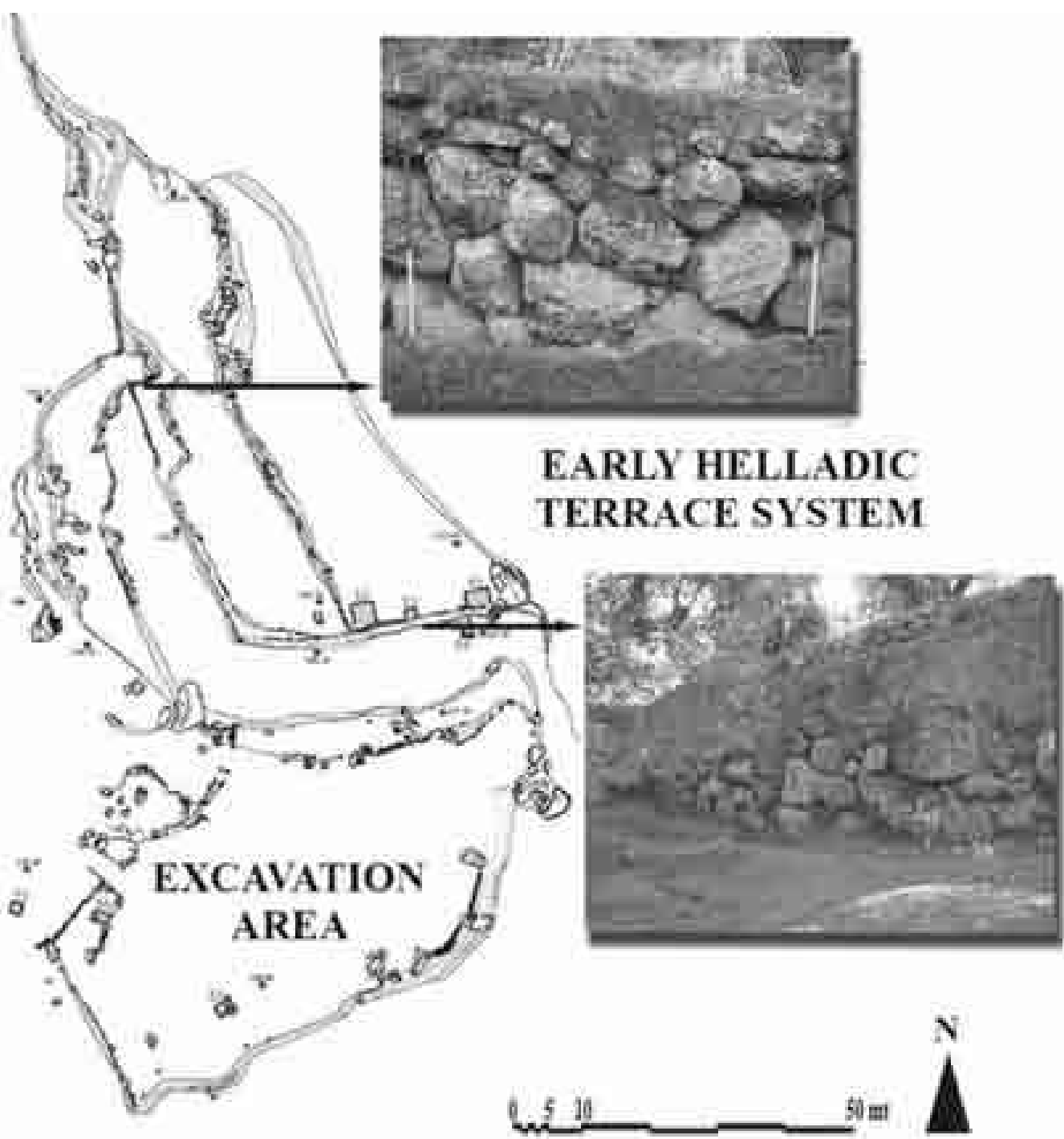

Along the western edge of the plateau, characterised by the presence of rocky slopes, the sclerophyllous Mediterranean maquis species gradually give way to species typical of thermo-mesophilous woods (Bussotti et al.,2005) .

Here one finds the Aleppo pine associated with the European black pine; the terebinth replaces the mastic and deciduous oaks, such as the Downy oak, begin to appear.

In the deep natural channels that surround the rest of the plateau, in which flow the Krios, Chalandra and Goulas, the vegetation becomes more clearly riparian, composed mainly of plane trees and oleanders.

\section{Archaeobotanical analysis}

The archaeobotanical analyses of the material gathered at the site, from hearths and floors in household structures and under the walls of the terraces archaeologically dated to Early Helladic Period, yielded a number of plant macroremains that were used to reconstruct the characteristics of the past vegetation. The recovered remains were charred fragments of secondary woody tissue, seeds and/or fruits.

In total 487 charcoals were identified, corresponding to 14 taxa (Fig. 7) and 16 macroremains of seeds and/or fruits, corresponding to 5 taxa.

An important feature was the considerable concentration of remains of Olea, although it was not possible to establish whether these belong to the wild and/or cultivated variety. Other Mediterranean maquis plants that were identified include mastic (Pistacia lentiscus), evergreen oaks (Quercus sp. evergreen type), tree heath (Erica cf. arborea) and pines (Pinus type brutia-halepensis) (Fenaroli, 1998; Gaudenzio et al.,2002) . 


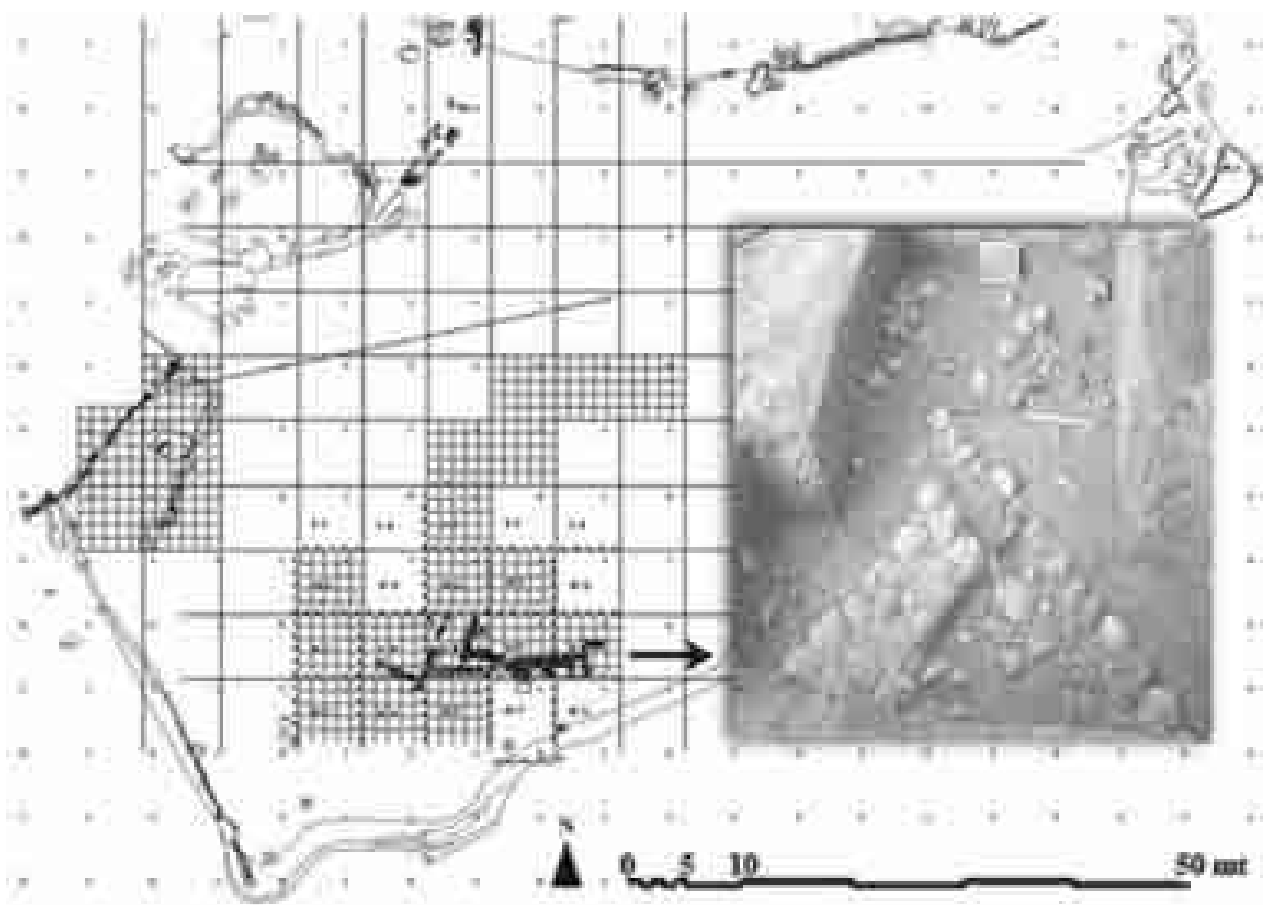

Figure 5: Grid of archaeobotanical sampling.

Figure 5: Grille des prélèvements archéobotaniques.
There was also a conspicuous number of charcoals of terebinth (Pistacia terebinthus) and deciduous oak (Quercus sp. deciduous type), generally associated with thermo-mesophilous environments.

The remaining fragments were poplar (Populus sp.) and plane tree (Platanus orientalis) probably from woods growing near watercourses (Sfikas, 1983).

As well as remains of charred woody tissue, a small quantity (16 items) of seed and fruit remains of trees and herbaceous plants were also recovered (Fig. 7). Of these, carbonised remains of fig syconia (Ficus carica) accounted for most of the finds. There was also an emmer wheat caryopsis (Triticum dicoccum), a goosegrass achene (Galium aparine) and a grape seed (Vitis vinifera). The rounded shape of the latter, according the archaeobotanical literature (Stummer, 1911; J.M. Renfrew 1973; Mangafa \& Kotsakis, 1996), requires further analyses in order to establish whether it is a cultivated variety (Vitis vinifera subsp. vinifera) or a wild type (Vitis vinifera subsp. sylvestris).

\section{DisCuSSION AND CONCLUDING REMARKS}

The archaeobotanical analyses of material from the site of Kassaneva and the reading of the current vegetation allow us to advance a series of hypotheses about the characteristics of the palaeoenvironment in the course of the $3^{\text {rd }}$ millennium
$\mathrm{BC}$ in the region of Aegialia. The remains of woody tissue from various trees used as fuel in household and craft activities illustrate the composition of the vegetation surrounding the settlement and at the same time allow us to describe its catchment area and the way it was exploited.

Though limited, the taxonomic range (14 tree taxa) highlights the presence of ecologically distinct environments, as well as modern vegetation survey suggests (Fig. 6). Specifically, adjacent to the sclerophyllous evergreen species that are typical of the xerophilous environment of the lowland areas (Olea europaea, Quercus sp. evergreen type, Ficus carica, Prunus sp. and Pistacia lentiscus), there are trees typical of riparian environments (Populus sp. and Platanus orientalis) found in river valleys that were more accessible in ancient times than they are now (Petropoulos et al. 2004). In contrast, the remains attributed to thermo-mesophilous species (cf. Cupressus, Quercus sp, Quercus sp. decidous type, Erica cf. arborea and Pinus type brutia-halepensis) identify a third environment corresponding to the hillsides. These are heights near the settlement that stretch inland, where the increasing altitude is associated with moderately cooler temperatures and increased precipitation (Dufaure, 1975).

The varying degree of exploitation of the different types of environment is shown in the pie chart, which excludes data concerning olive trees due to their evident over-representation (Fig. 8). It emerges that the vegetation most affected by human pressure by fuel gathering is that of the xero- 


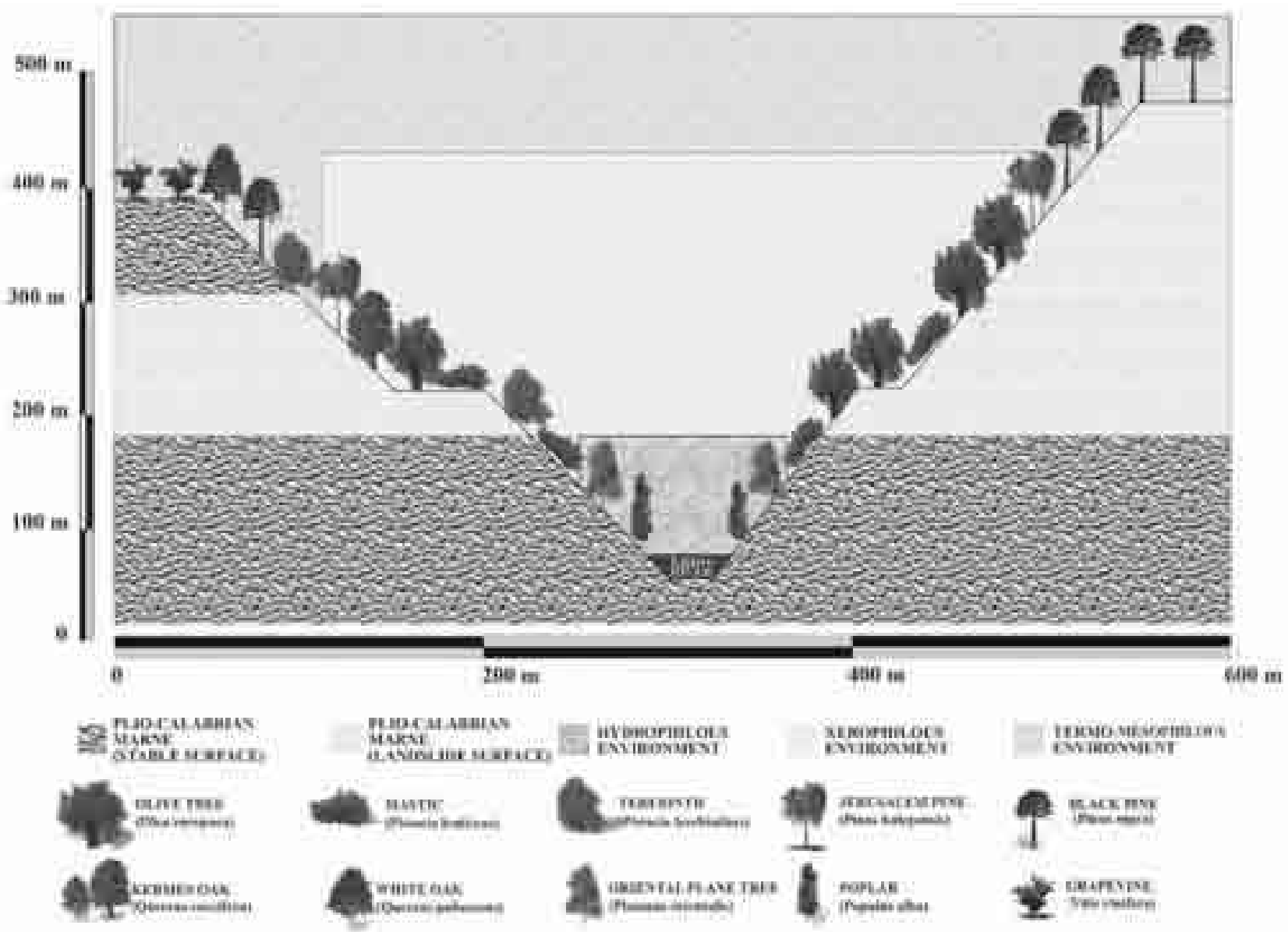

Figure 6: Modern vegetation pattern in the Krios valley.

Figure 6 : Modèle de la végétation moderne dans la vallée de Krios.

philous maquis, presumably situated in the lowland areas (accounting for 39\% of the finds). The surface area covered by this type of vegetation is governed, as in the past, by natural boundaries, such as the deep channels of the rivers Chalandra, Krios and Goulas, situated to the north, east and south of the plateau respectively.

The thermo-mesophilous vegetation (24\%) highlights the exploitation of the hilly areas to the west of the settlement. It is probable that the deciduous oaks, found on the hills, were used for carpentry.

The riparian trees (18\%) constitute something of a novelty. The current topography of the terrain near the watercourses is probably the result of a process of gradual erosion that has made these areas more inaccessible than in the past.

In this regard, the terracing that is still visible in the area is evidence of the careful management of space in terms of both slowing down the process of erosion and exploiting the land for agriculture.
The carpological data recovered at the site are still too limited to allow reconstruction of the characteristics of the crops. However, the presence of an emmer wheat caryopsis is evidence of the use of cereals that are particularly hardy and suitable even for cultivation in hilly environments. The presence of the grape seed and the uncertainty as to the subspecies (i.e. whether it was a cultivated or a wild variety) means that there may have been vines among the natural vegetation, particularly as a climber near the rivers. The presence of the two olive endocarps and the over-representation of fragments of charred woody tissue from olive trees require a fuller account.

The use of olives as a plant to be eaten directly as food or pressed to obtain oil is at the centre of a lively debate on the origin of olive cultivation in the Aegean region in the course of the $3^{\text {rd }}$ millennium BC. Renfrew's hypothesis concerning the birth of olive cultivation in accordance with a model of endogenous development dating back to the 

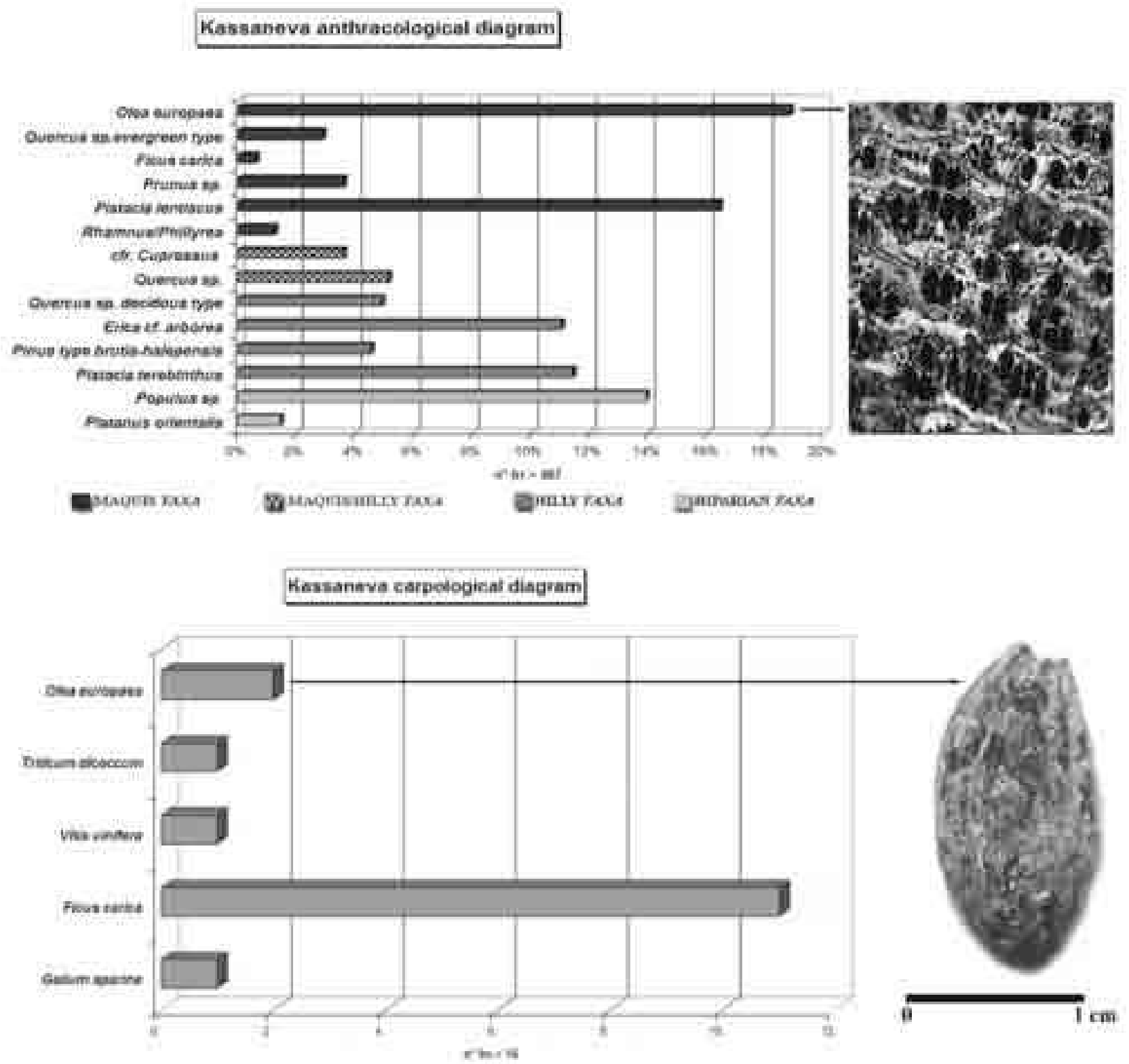

Figure 7: Anthracological diagram with transversal section of olive-wood charcoal (Olea europaea) (100x) and carpological diagram with olive stone (Olea europaea)( 10x).

Figure 7 : Diagramme anthracologique avec section transversale de charbon de bois d'olivier (Olea europaea) (100x) et diagramme carpologique avec endocarpe d'olivier (Olea europaea) (10x).

pre-palatial period (3650-1900 BC) (A.C. Renfrew, 1972), with specific reference to remains of endocarps discovered in Myrtos (Crete) together with remains of branches believed to have been pruned (Rachkam, 1972; J.M. Renfrew, 1973), has been contested (Hamilakis, 1986; Runnels \& Hansen, 1996). The quantities involved are not considered sufficient proof of cultivation. Recently the hypothesis of olive cultivation in the course of the Ancient Bronze Age was proposed on the basis of remains recovered from the site of Akrotiri on Santorini (Asouti, 2003). The problem remains unsolved due to the complex biometric distinctions between the seeds of the different varieties (Buschan, 1895). However, recent approaches based on geometric morphometry seem to provide new tools for distinguishing wild from cultivated subspecies, working with either seeds (Terral et al., 2004) or wood charcoal (Terral \& Arnold-Simard, 1996; Terral, 
Figure 8: Exploitation of the different types of environment.

Figure 8 : Exploitation des différents types d'environnement.
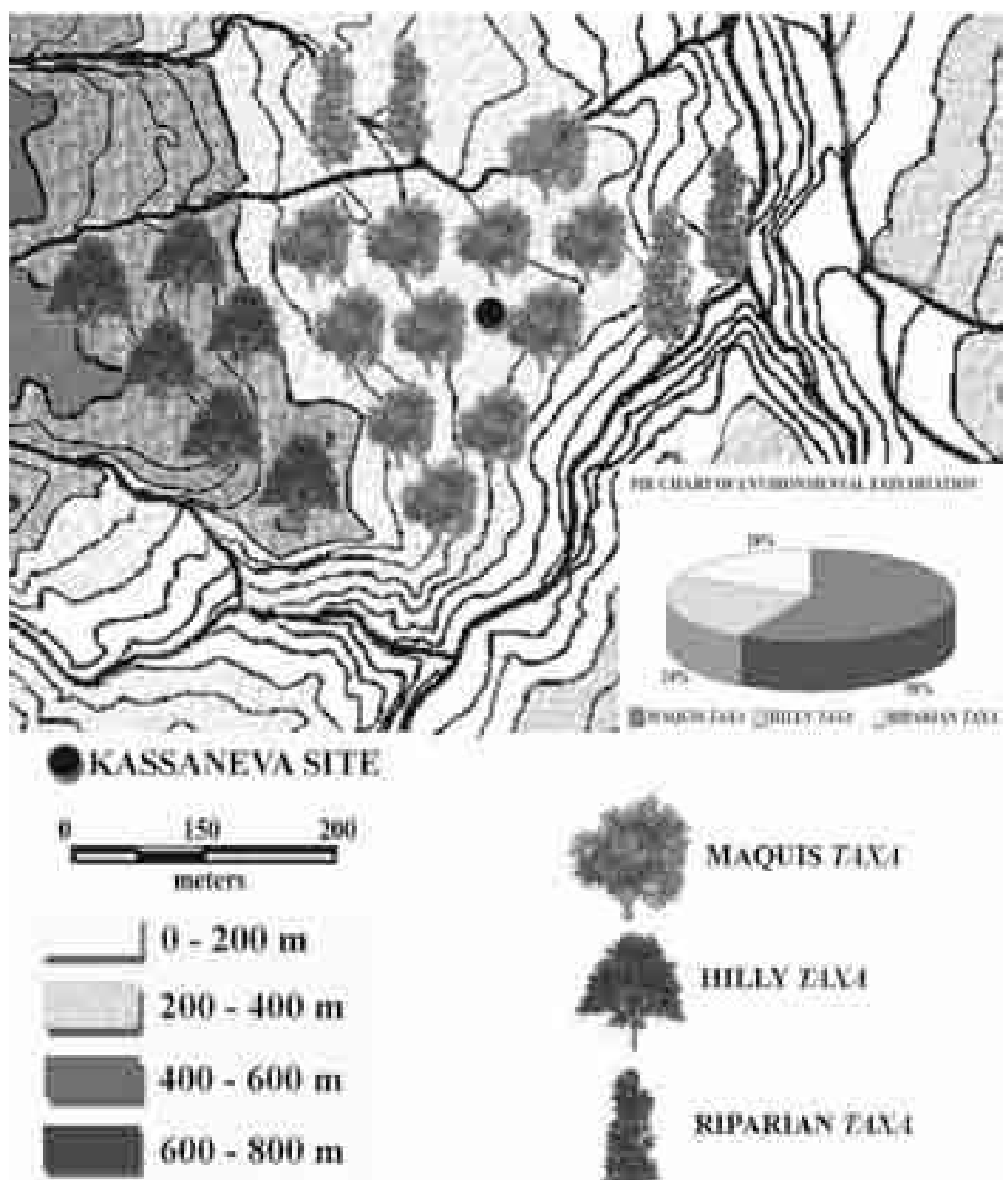

RIPARIAY TAXA
2000). The high heterozygosity of the olive tree and the use of asexual reproduction for cultivation purposes make the distinction between wild and cultivated plants even more complex (Zohary \& Hopf, 2000).

The abundant discoveries of olive remains in Aegean region, both endocarps and woody tissue, and the presence of equipment for the production of oil, seem to indicate that cultivation began during the post-palatial period (14001100 BC) (Hamilakis, 1986; Runnels \& Hansen, 1996).

In this framework the archaeobotanical data of the Kassaneva site highlight the special role of olives among the local Early-Helladic communities. The species was certainly present in the natural vegetation of the xerophilous environment of the Mediterranean maquis and in the thermomesophilous hilly areas, together with oaks and terebinth. It was exploited not only as a fuel but probably also to obtain materials for carpentry (Fiorentino \& Solinas, 2008) and for fruits. In this regard, the archaeobotanical data are still scarce but the analysis of the anthropic components of the landscape highlight terracing, whose purpose was probably olive cultivation. Further archaeobotanical analyses will provide a better understanding of the dynamics of this process in an apparently marginal area of the Peloponnese.

\section{References}

Abbate Edlmann, M.L., de Luca, L. and Lazzari, S., 1994 Atlante anatomico degli alberi ed arbusti della macchia mediterranea. Istituto agronomico per l'Oltremare, Firenze.

Andergerg, A.L., 1994 - Atlas of seeds-Part 4. ResedaceaeUmbellifera. Swedish Museum of Natural History, Stockholm. 
Asouti, E., 2003 - Wood charcoal from Santorini: new evidence for climate, vegetation and timber imports in the Aegean Bronze Age. Antiquity, 77, (297): 471-484.

Bintliff, J., 2008 - "In praise of the ancestors". Catchment and territory in agricultural landscape: revisiting the birth of a concept in the light of current research in landscape archaeology. In C. Gallou, M. Georgiadis and G. M. Muskett (dir.), Dioskouroi. Studies presented to W.G. Cavanagh and C.B. Mee on the anniversary of their 30 year joint contribution to Aegean Archaeology. British Archaeological Reports, International Series 1889. Oxford, 216-226.

Buschan, G., 1895 - Vorgeschichtliche Botanik der Kultur - und Nutzplanzen der alten Welt auf Grunde prähistorischer Funde. Breslau.

Bussotti, F., Piccini, C., Piotto, B. and Cervelli, C., 2005 Le specie arbustive della macchia mediterranea - un patrimonio da valorizzare. Edizioni del Dipartimento Azienda Regionale Foreste Demaniali, Palermo.

Butzer, K.W., 1996 - Ecology in the long view: settlement histories, agrosystemic strategies, and ecological performance. Journal of Field Archaeology, 23: 141-150.

Cambini, A., 1967 - Riconoscimento microscopico del legno delle querce italiane. Contributi Scientifico-pratici per una migliore conoscenza ed utilizzazione del legno. Vol. X (20). CNR. Roma.

Cavanagh, W., Mee, C. and James, P., 2005 - The Laconia rural sites project. British School at Athens, London.

Cherry, J., Davis, J. and Mantzourani, E., 1991 - Landscape Archaeology as Long-Term History: Northern Keos in the Cycladic Islands from Earliest Settlements until Modern Times. Monumenta 16, University of California, Los Angeles.

Dafis, S., 1976 - Classification of forest vegetation of Greece. Ministry of Agricolture-General Direction of Forest, Publication 36, Athens.

Davis, J.L. and Sutton, S.B., 1995 - Response to A.J. Ammerman, "The Dynamics of Modern Land Use and the Acconia Survey". Journal of Mediterranean Archaeology, 8, (1): 113-123.

Dufaure, J.J., 1975 - Le relief du Péloponnèse. Thèse d'Etat, Université de Paris-Sorbonne, France.

Fenaroli, L., 1998 - Flora mediterranea. Atlanti natura Giunti, Milano

Findlow, F.J. and ERICson, J.E., 1980 - Catchment analysis: essays on prehistoric resource space. University of California, Los Angeles.

Fiorentino, G. and Solinas, F., 2008 - Carboni e carporesti dal palazzo di Monastiraki, campagne 2002/2004. Quaderni della Ricerca Scientifica. Serie Beni Culturali, 4, Napoli.

Gaudenzio, P., Peccenini S., Gaudenzio, P. and Solari M., 2002 - La macchia mediterranea. Formazioni sempreverdi costiere. Quaderni habitat, Ministero dell'Ambiente e della Tutela del Territorio. Museo Friulano di Storia Naturale - Comune di Udine, 6, Udine.

Gavrielides, N., 1976 - The impact of olive growing on the landscape in the Fourni valley. Annals of the New York Academy of Science, 268: 143-147.

Greguss, P., 1955 - Identification of living gymnosperms on the basis of xylotomy. Akadémiai Kiadó, Budapest.

Hamilakis, Y., 1986 - Wine, oil and the dialectics of power in Bronze Age Crete: a review of the evidence. Oxford Journal of Archaeology, 5, (3): 1-32.

Higgs, E.S. and Vita Finzi, C., 1972 - Prehistoric economies: a territorial approach. In E.S. Higgs (dir.). Papers in Economic Prehistory, Cambridge University Press, Cambridge, 27-36.

JACOMET, S., 2006 - Identification of cereal remains from archaeological sites. Basel University, Basel.

Jacquiot, C., 1955 - Atlas d'anatomie des bois des coniferes. Centre Technique du Bois, Paris.

Le Roy Ladurie, E., and Barry, J.P., 1962 - Histoire agricole et phytogéographie. Annales. Économies, Sociétés, Civilisations, 17, (3): 434-447.

LEE, W.E., 2001 - Pylos regional archaeological project, part IV: change and the human landscape in a modern greek village in Messenia. Hesperia 70: 49-98.

Lloyd, J.A., Owens, E.J. and Roy, J., 1985 - The Megalopolis Survey in Arcadia. In S. Macrealy and H. Thompson (dir.). Archaeological Field Survey in Britain and Abroad, Society of Antiquaries Occasional Papers 6, London, 217-224.

Malanson, G.P. and Trabaud, L., 1988 - Vigour of post-fire resprouting by Quercus coccifera L. Journal of Ecology 76: 351365.

Mangafa, M. and Kotsakis, K., 1996 - A new method for the identification of wild and cultivated charred grape seeds. Journal of Archaeological Science 23: 409- 418.

Petropoulos, M., Pontrandolfo, A. and Rizakis, A.D., 2002 - Prima campagna di ricognizioni archeologiche in Egialea (settembre-ottobre 2002). Annuario della Scuola Archeologica Italiana di Atene, 80: 234-237.

Petropoulos, M., Pontrandolfo, A. and Rizakis, A.D., 2003 - Seconda campagna di ricognizioni archeologiche in Egialea (aprile-maggio, settembre, ottobre 2003). Annuario della Scuola Archeologica Italiana di Atene, 81: 947-961.

Petropoulos, M., Pontrandolfo, A. and Rizakis, A.D., 2004 - Terza campagna di ricognizioni archeologiche in Egialea (settembre-ottobre 2004). Annuario della Scuola Archeologica Italiana di Atene, 82: 783-806.

Petropoulos, M., Pontrandolfo, A. and Rizakis, A.D., 2005 - Quarta campagna di ricognizioni archeologiche in Egialea (settembre-ottobre 2005). Annuario della Scuola Archeologica Italiana di Atene, 83: 679-716. 